\section{The Monetary policy in the Republic of North Macedonia and Republic of Albania during 2020}

\section{Monetarna politika u Republici Sjevernoj Makedoniji i Republici Albaniji tijekom 2020. godine}

\begin{abstract}
Globally, the COVID-19 pandemic crisis is considered as one of the worst global recessions in history, caused by non-economic factors such as the coronavirus pandemic. The pandemic crisis has increased the financial stability and vulnerability across different markets and sectors. These changes required the central banks, governments, and other authorities to take a variety of policy assistance steps to help limit immediate financial stability threats. The goal of this study is to examine how the monetary policies of the Republic of North Macedonia and Republic of Albania, as one of the two key macroeconomic policies, have reacted in response to COVID 19 for the year 2020. This study looks at how the central banks of both countries have altered conventional and unconventional monetary policy tools to combat the pandemic. The analysis is based on the data published by the monetary officials in both countries. The results show that interbank interest rates in the Republic of North Macedonia and Republic of Albania were reduced from $2.00 \%$ to $1.50 \%$ and from $1.00 \%$ to $0.50 \%$, respectively, while overnight loan interest rates were reduced from $2.50 \%$ to $2.00 \%$ and from $1.90 \%$ to $0.90 \%$, respectively. An overview of the unconventional measures is also presented.
\end{abstract}

Keywords: monetary policy, central bank, conventional monetary tools, unconventional monetary tools

JEL classification: E49, E58, E59

\section{Sažetak}

Pandemijska kriza COVID-19 smatra se jednom od najgorih globalnih recesija u povijesti,uzrokovanom neekonomskim čimbenikom - pandemijom koronavirusa. Pandemijska kriza povećala je financijsku ranjivost na različitim tržištima i sektorima. Ove promjene zahtijevale su od središnjih banaka, vlada i drugih tijela da poduzmu niz mjera kako bi se ograničile neposredne prijetnje financijskoj stabilnosti. Cilj ovog rada je analizirati kako su monetarne politike Republike Sjeverne Makedonije i Republike Albanije, kao jedne od dvije ključne makroekonomske politike, odgovorile na pandemiju COVID-19 tijekom 2020. godine. Rad razmatra kako su središnje banke obiju zemalja primijenile konvencionalne i nekonvencionalne alate monetarne politike u borbi protiv pandemije. Analiza se temelji na podacima središnjih banaka obiju zemalja. Rezultati pokazuju da su međubankovne kamatne stope u Republici Sjevernoj Makedoniji i Republici Albaniji smanjene s 2,00\% na 1,50\%, odnosno s 1,00\% na 0,50\%, dok su kamatne stope na prekonoćne kredite smanjene s 2,50\% na 2,00\% i s $1,90 \%$ na $0,90 \%$. Također, dan je i pregled primijenjenih nekonvencionalnih mjera.

Ključne riječi: monetarna politika, središnja banka, konvencionalni monetarni alati, nekonvencionalni monetarni alati

JEL klasifikacija: E49, E58, E59

\section{Shenaj Hadzimustafa}

Assoc. prof.

South East European University, Republic of North Macedonia

E-mail: s.daut@seeu.edu.mk

\section{Hyrije Abazi-Alili}

Assoc. prof.

South East European University, Republic of North Macedonia

E-mail: h.abazi@seeu.edu.mk

\section{Shenaj Hadzimustafa}

Izv. prof.dr.sc.

South East European University, Republic of North Macedonia

E-mail:s.daut@seeu.edu.mk

\section{Hyrije Abazi-Alili}

Izv. prof. dr.sc.

South East European University, Republic of North Macedonia

E-mail:h.abazi@seeu.edu.mk 
Hadzimustafa, S., Abazi-Alili, H.

The Monetary policy in the Republic of North Macedonia and Republic of Albania during 2020

\section{Introduction}

As a one-of-a-kind event in recent economic history, the COVID 19 health crisis necessitated increased public health protection and the implementation of measures to stop the virus from spreading further. A different set of strict protective measures were taken within the national economies, depending on the extent to which they were hit by the virus. This caused a substantial drop in the second quarter of 2020, with a considerable negative impact on the country's economic performance. As the countries implemented steady easing policies over the years, combined with macroeconomic policy stimulus, their economic performance improved.

In normal times, conventional monetary policy tools such as expanding the money supply and lowering interest rates are sufficient to keep the economy stable. However, when the economy is in a full-fledged crisis, such as the current pandemic or the previous financial crisis, conventional monetary policy tools are ineffective. During normal times, the central bank's three monetary policy tools to control the money supply and interest rates are: open market operations, discount lending, reserve requirements and interests on reserves (Hubbard and O'Brien, 2012). These three tools are referred to as conventional monetary policy tools. When the zero-lower-bound problem occurs, conventional monetary policy tools are no longer effective because the central bank is unable to lower shortterm interest rates because they have reached a floor of zero. In this situation standard monetary policy becomes ineffective at combating a falling money supply and economic recessions. To stimulate the economy, central banks require non-interestrate tools known as nonconventional monetary policy tools. Key nonconventional monetary policy tools that are used when conventional policy is no longer effective are: liquidity provision, asset purchases, forward guidance, and negative interest rates on central bank deposits (Mishkin, 2019).

During 2020 the global economy fell by $3.5 \%$. The COVID 19 health crisis is assessed as the greatest global recession since the Great Depression in 1930. Based on the given situation, the paper's goal is to give an overview of the measures undertaken by the monetary authorities in the EU and USA and later focus on the anti-crisis monetary policy measures implemented by the central banks of the Republic of North Macedonia and the Republic of Albania.

The main questions addressed in the paper are: how have conventional tools changed in these two countries? Did the central banks in the two countries apply unconventional tools, and if so, what kind? And as a conclusion, is an expansive or restrictive monetary policy pursued to deal with the pandemic situation in the two analysed countries?

The paper's structure is subordinate to its stated analytical purpose. The paper begins with an overview of the literature in this area, then moves on to the methodology used in the paper, followed by case study analyses of the monetary policies in the two countries, and concludes with conclusions and recommendations.

\section{Literature review and background}

The unprecedented and severe coronavirus (COVID-19) pandemic shock devastated the Eurozone economy in 2020. As a result of the lockdown measures and increased risk aversion, economic activity fell dramatically in the first half of the year. The second half of the year saw activity stabilize thanks to a strong and coordinated monetary and fiscal policy response, as well as favourable vaccination news. In 2020, the euro area's GDP shrank by $6.6 \%$ (Figure 1). Annual headline inflation fell to $0.3 \%$ in 2020 from $1.2 \%$ in 2019. This is due to lower energy prices, decreased demand in the industries that were hardest hit by the crisis, such as transportation and hotels, and other pandemic variables.

Considering the incidence of the illness and the implemented preventive measures, the RNM and Albanian economies did not depart from global trends. During 2020 the GDP growth rates in these two countries fell by 4.5 and $3.3 \%$, respectively (Figure 2).

To counteract the pandemic's negative impacts, developed-country central banks implemented stimulatory monetary policies in 2020. In addition, we will see what measures the FED, the ECB, and the central banks of Albania and North Macedonia have taken in this period. As a result, the FED cut the interest rate twice in March to a range of $0 \%$ to $0.25 \%$, increased the offer in the repo 
Figure 1 GDP in selected world countries (annual percentage changes)

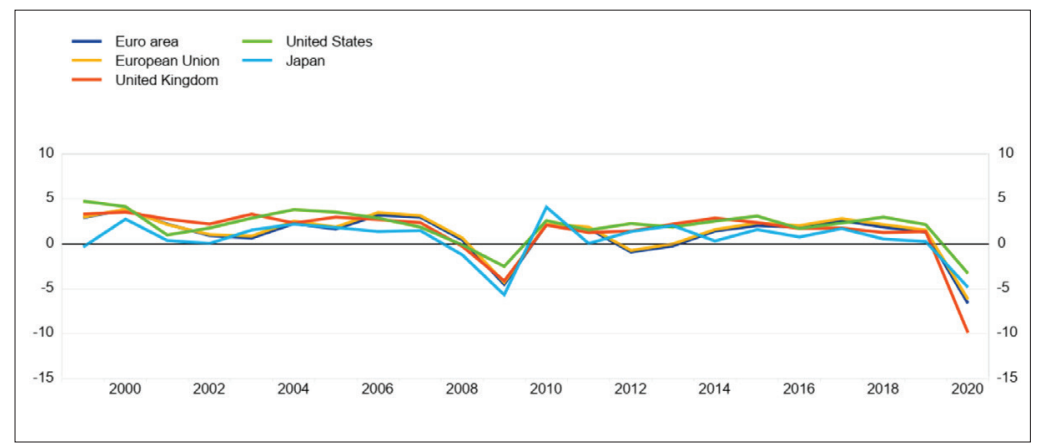

Source: ECB (2021a).

Figure 2 GDP growth in North Macedonia and Albania (in \%)

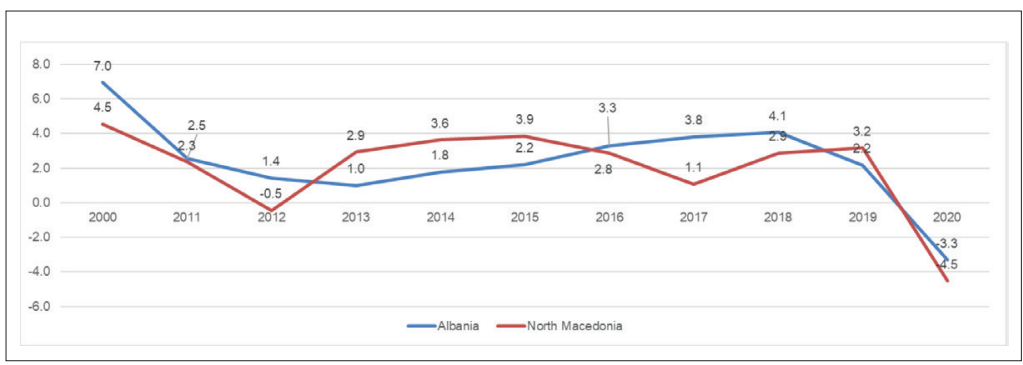

Source: World Development Indicators (2021).

Figure 3 FED's assets

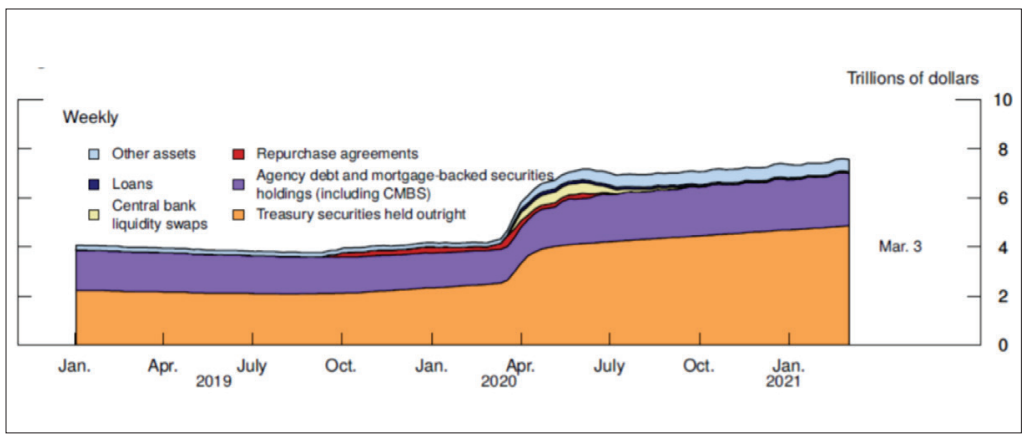

Source: Clarida et al. (2021). 
Hadzimustafa, S., Abazi-Alili, H.

The Monetary policy in the Republic of North Macedonia and Republic of Albania during 2020 agreements, and changed the timing, amount, and maturity structure of the repo government bonds. The quantitative easing program was implemented to encourage lending to families and companies to boost the availability of US dollar liquidity. Additionally, the FED offered forward guidance on rates and asset purchases. In August, the FED changed the strategy for conducting monetary policy concerning the inflation rate, allowing room for a higher inflation rate than the previously set inflation target of $2 \%$. The Fed's changed balance sheet's assets are given in Figure 3, below (Clarida et al., 2021).

Like the FED, as a response to the pandemic's serious impact on the euro area economy, the European Central Bank (ECB) significantly softened its monetary policy through a comprehensive series of measures that were re-calibrated throughout the year. This includes (ECB, 2021b):

- introducing a new, temporary, pandemic emergency purchase program

- relaxing eligibility and collateral criteria and

- offering new, longer-term refinancing operations.

In 2020, the ECB introduces quantitative easing of 120 billion euros and repurchases of securities of 20 billion euros monthly under the regular asset purchase programme (APP), followed by 1,850 billion euros for the implementation of the Temporary Securities Purchase Program for the immediate support of the economy, called pandemic emergency purchase programme (PEPP), which includes additional private and public sector asset purchases.

The targeted longer-term refinancing operations (TLTRO) have become an important source of funding for the European banking sector, while emergency lending arrangements in the United States mostly serve as a market backstop. The TLTRO's success in averting a credit crisis and safeguarding the monetary policy transmission mechanism is evidenced by the substantial rise in lending to corporations at the start of the pandemic Banks' robust involvement in the TLTROs was assisted by the relaxation of collateral requirements in lending operations, which facilitated the availability of bank credit to very small businesses, which are particularly reliant on bank funding as shown in Figure 4 (ECB, 2021c).

In addition, the terms of the third package of specific long-term repos (TLTRO III) have been softened three times, many security measures have been adopted, and a new series of seven pandemicrelated long-term repos have been carried out pandemic emergency longer-term refinancing operations (PELTRO), which will also last until 2021. To keep the financial system stable during the pandemic crisis, the ECB recommends that banks should be careful with their dividend policies.

Figure 4 High take-up of TLTROs and a sharp rise in bank lending to firms

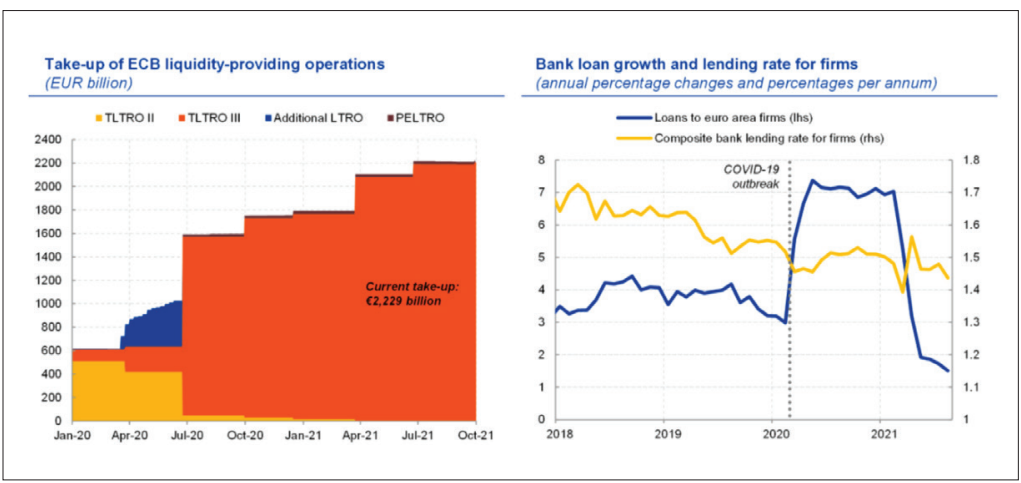

Source: ECB (2021c). 
Furthermore, the ECB decided to introduce swap and repo lines (Eurosystem repo facility for central banks, EUREP) for central banks outside the ESCB, including a repo line for the NBRM (NBRM, 2021).

Central banks have four main monetary policy tools: the reserve requirement, open market operations, the discount rate, and interest on reserves. Most central banks also have a lot more tools at their disposal. These tools can either help expand or contract economic growth. In addition to conventional tools during the crisis, unconventional monetary policy tools have been used because of the need to cope even better with the consequences during and after the crisis, such as quantitative easing, forward guidance, collateral adjustments, and negative interest rates. During the global financial crisis, to complement conventional monetary policies, central banks implemented unconventional measures to pull their economies out of financial distress.

According to Loayza and Pennings (2021), the effects that COVID-19 has caused on global public health and the global economy could surpass those from the 2008-09 global financial crisis. The measures being undertaken should prevent the spread of the virus, which, on the other hand, causes a reduction in the economic performance of the countries. This situation limits policymakers' ability to implement policies that have a positive socioeconomic impact in their respective countries.

In accepting the inaugural Miriam Pozen Prize, Stanley Fischer, ex-vice chair of the US Federal Reserve, governor of the Bank of Israel, and World Bank chief economist, says that unconventional monetary policies, such as corporate and municipal bonds, "were critical to halting the downward spiral of markets, lessening pandemic-driven lines [and] losses of businesses, and jump-starting the economic recovery" (MIT, 2021). Countries' policies must get used to these measures as being critical in solving future economic crises.

\section{Methodology}

The analysis in the paper was based on the official data published on the official websites of the central banks of the two countries, which provided the necessary information needed to identify the changes in the monetary policy seen through conventional and unconventional monetary tools in both countries. When analysing the conventional assets, monthly quantitative data on the interest rates of conventional monetary policy tools, such as open market operations, required reserve ratio, available reserves, overnight and overnight loans, were obtained for the Republic of North Macedonia. Open market operations required reserve ratio, available reserves, liquidity management, and monetary policy implementation were all examined for Albania. The analysis is based on the year 2020. The data was used to perform dynamic analysis to see volatility both at baseline and relative magnitude.

The data is being used to assess how the monetary policies in the Republic of North Macedonia and Albania changed to cope with the pandemic situation and to see if any unconventional tools were being used for this purpose.

\section{Empirical evidence}

During the pandemic situation, different monetary authorities worldwide have used conventional and unconventional tools to smoothen the negative effects that the pandemic situation has caused on the economies. The set of tools that were used by NBRM in 2020 was as follows: conventional tools such as open market operations, required reserve ratio, and overnight loans; and unconventional tools such as reactivation of the non-standard reserve demand measure, expansion of the portfolio of eligible securities, tariff reduction, and extension of the deadlines for loans and the bank's liquidity assessment report, are used by the central bank of this country to change its monetary policy.

The Central Bank of the Republic of Northern Macedonia's main purpose is to maintain price stability and financial stability in the country by not compromising the realization of the main goal while respecting the principles of the market economy. To achieve the main goal, it indirectly influences through the management of the conventional tools of this policy, such as open market operations, required reserve ratio, overnight deposits, seven-day deposits, and overnight loans.

The Central Bank of the Republic of Albania's main purpose is to maintain price stability. It achieves this main goal indirectly through the
Hadzimustafa, S., Abazi-Alili, H.

The Monetary policy in the Republic of North Macedonia and Republic of Albania during 2020 
Hadzimustafa, S., Abazi-Alili, H.

The Monetary policy in the Republic of North Macedonia and Republic of Albania during 2020 management of conventional policy tools such as open market operations, required reserve ratio for overnight deposits, overnight loans, and liquidity management, and monetary policy implementation (Bank of Albania, 2021).

According to The National Bank of North Macedonia's annual reports (2020), the NBRM released its monetary policy during 2020 as well, to mitigate the negative effects of the COVID-19 crisis. This strategy is in cooperation and harmony with the fiscal policy of the country. The Bank of Albania took rapid action in reaction to the pandemic scenario to assist the Albanian economy, which had been damaged by the coronavirus epidemic. In this regard, the Bank of Albania's actions, which fall within its scope, enable, and complete the fiscal package outlined by the Albanian government, which aims to move a part of the financial bill to combat the crisis from the private to the public sector (Bank of Albania, 2020b).

A timely and coordinated monetary and fiscal policy response smooths and combats the effects of the crisis on the economy. The National Bank of North Macedonia used the instruments to improve access to liquid funds for economic agents and have fewer adverse consequences.

As a result of increased liquidity support for the banking system, the National Bank released a portion of the excess liquid assets of banks twice by lowering the amount of the reserve requirement by 15 billion denars while lowering the key interest rate to an all-time low of $1.5 \%$. The introduction of the nonstandard reserve requirement measure aided the real economy by providing targeted credit support to the most vulnerable sectors.

\section{Results and discussion}

Because the supply of foreign currency put pressure on the foreign exchange market, the National Bank reacted rapidly and with relatively strong monetary easing through a variety of monetary instruments at the start of the crisis. As a result, in response to the pandemic's projected highly negative impacts and to ease the conditions for financing the real sector, the main interest rate was cut by 0.50 percentage points on two occasions (in March and May) to an all-time low of 1.5\%. The National Bank cut the amount of CB bills by 15 billion denars in April and May, bringing the total amount to 10 billion denars. The National Bank released 60\% of the banking system's liquid assets withdrawn through this instrument by lowering the supply of CB bills, making room for enhanced credit support to the domestic sector.

All the changes in the conventional tools of the country's monetary policy during 2020 are presented in Figure 5, while the required reserves ratio is presented in Table 1. The dynamic analysis shows that the interbank interest rate decreased relatively slightly more than the overnight loan

Figure 5 Interest Rates of conventional Monetary Policy Tools (except Required Reserve) in the Republic of North Macedonia in 2020

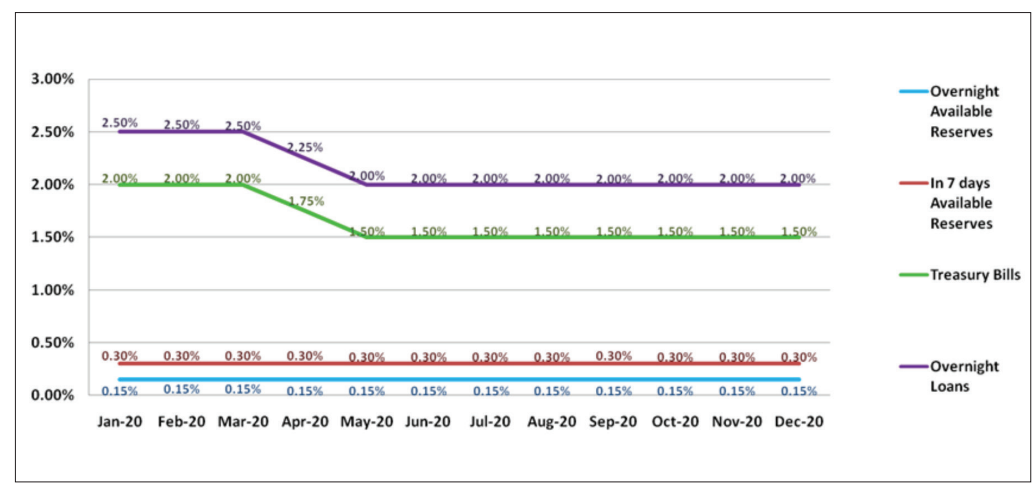

Source: NBRM (2020a), author's calculation. 
Table 1 Reserves Requirement Ratios in the Republic of North Macedonia and Albania in 2020

\begin{tabular}{|c|c|c|c|}
\hline North Macedonia & & Albania & \\
\hline $\begin{array}{l}\text { Banks' reserve requirement } \\
\text { ratios - in domestic currency }\end{array}$ & $8.00 \%$ & $\begin{array}{l}\text { Banks' reserve requirement } \\
\text { ratios in domestic currency - } \\
\text { maturity term of liabilities up } \\
\text { to } 12 \text { months }\end{array}$ & $7.50 \%$ \\
\hline $\begin{array}{l}\text { Banks' reserve requirement } \\
\text { ratios - in domestic currency } \\
\text { with FX clause }\end{array}$ & $50.00 \%$ & $\begin{array}{l}\text { Banks' reserve requirement } \\
\text { ratios in domestic currency } \\
\text { - maturity term of liabilities } \\
\text { over } 12 \text { months to } 2 \text { years }\end{array}$ & $5.00 \%$ \\
\hline $\begin{array}{l}\text { Banks' reserve requirement } \\
\text { ratios - in foreign currency }\end{array}$ & $15.00 \%$ & $\begin{array}{l}\text { Banks' reserve requirement } \\
\text { ratios - in foreign currency }\end{array}$ & $\begin{array}{l}12.50 \% \\
20.00 \%\end{array}$ \\
\hline $\begin{array}{l}\text { Reserve requirement ratio of } \\
\text { savings houses }\end{array}$ & $2.50 \%$ & & \\
\hline
\end{tabular}

Source: NBRM (2020b) and Bank of Albania (2020c).

interest rate. In April, 2020 the interbank interest rate decreased by $13 \%$, from $2.00 \%$ to $1.75 \%$ and the overnight loan interest rate by $10 \%$, from $2.50 \%$ to $2.25 \%$. In May, 2020 the interbank interest rate was cut by $14 \%$ and fell to $1.50 \%$, and the overnight loan interest rate was cut by $11 \%$, decreasing further to $2.00 \%$.

Given that changes in traditional tools have a finite lifespan, the required reserve ratio in both North Macedonia and Albania did not change during the analyzed 2020 pandemic crisis period (Table1).

The unconventional tools that were also used by the National Bank of the Republic of North Macedonia can be summarized as follows (NBRM, 2020c, 2020d):

- The reactivation of the non-standard reserve requirement measure, easing credit conditions in the most affected sectors of the pandemic crisis.

- Adding domestic government bonds with long-term maturities and Eurobonds issued by the state on foreign financial markets to the portfolio of approved instruments for obtaining liquidity for domestic banks from the National Bank.

- Tariff reduction. A decision was made to abolish fees charged so far for withdrawing and returning cash to the central vault of the National Bank. The council also approved a decision to remove the fee for providing data to individuals from the National Bank Credit Registry for their debt to banks and savings houses. Furthermore, a decision was made for all citizens in need to take the certificate from the Credit Registry for free.

- Extension of the deadlines for loans and the bank's internal liquidity assessment reports. This extension of the deadline for loans was prepared for enterprises and households that may face difficulties during this period due to the COVID-19 pandemic, and the decision for this extension was made twice during 2020 . Also, it was decided to extend the deadline for banks to submit their first internal liquidity assessment report.

- The ECB also opened a EUR 400 million repo line for the National Bank to supply foreign currency liquidity. This line is accessible until March 2022, and it provides additional room for the National Bank to act quickly and efficiently if foreign currency liquidity in euros is required by the country's banks.

According to the Bank of Albania reports (2020b, 2020c), the conventional tools of the Republic of Albania that were used changed as follows:

- Open market operations: the interest rates of treasury bills were decreased by 50 basis points from $1.00 \%$ to $0.50 \%$ in April and thus remained until the end of 2020.

- Required reserve: The required reserve ratios remained unchanged during 2020 as follows: The reserve ratio in lek was $7.50 \%$ for the liabilities included in the reserve base to which a 0 (zero) reserve ratio was not applied and
Hadzimustafa, S., Abazi-Alili, H.

The Monetary policy in the Republic of North Macedonia and Republic of Albania during 2020 
Hadzimustafa, S., Abazi-Alili, H.

The Monetary policy in the Republic of North Macedonia and Republic of Albania during 2020 with a maturity term up to 12 months; and $5.00 \%$ for the liabilities included in the reserve base to which a 0 (zero) reserve ratio was not applied with an initial maturity term of over 12 months to 2 years. The reserve ratio for foreign currency was $12.50 \%$ and $20 \%$.

- Overnight deposits: The overnight deposit interest rate remained unchanged at $0.10 \%$ throughout 2020.

- One-day loans: the interest rate of one-day loans decreased by 100 basis points from $1.90 \%$ to $0.90 \%$ in March and thus remained until the end of 2020 .

- Liquidity management and implementation of monetary policy: in terms of this monetary policy tool, routine forecasts of the need for liquidity are made simply and for different periods.

All the changes in the conventional tools of the country's monetary policy during 2020 are presented in Figure 6, while the required reserve ratios are presented in Table 1. The dynamic analysis shows that the interbank interest rate decreased relatively slightly more than the interest rate on overnight loans. In April, the interbank interest rate decreased by $50 \%$, from $1.00 \%$ to $0.50 \%$ and the overnight loan interest rate decreased by $53 \%$, from $1.90 \%$ to $0.90 \%$.

The unconventional tools of the Republic of Albania that were changed by the central bank can be summarized as follows (Bank of Albania, 2020d):

- Due to the difficult financial situation resulting from the pandemic, banks and nonbank financial entities were relieved to defer payment of loan instalments to their customers for six months. This only applied to clients whose financial deterioration was found because of the pandemic.

- Suspension of the dividend distribution of the banking sector: the distribution of the dividend of the banking sector is suspended during 2020.

- Reduction of infrastructure system electronics costs: the costs of commissions applied by banks for lek credit transfers in non-paper form from their customers were removed, as well as the fees for participants in the Albanian Interbank Payment System (AIPS) and Albanian Electronic Clearing House (AECH) operated by the Bank of Albania, starting April 10, 2020.

Based on the changes made to the conventional and unconventional tools, the conditions are met to conclude that an expansionary monetary policy was pursued in the Republic of Albania during the pandemic period of 2020.As a result of the changes applied to conventional tools, the volatility space for the interbank interest rate has changed towards narrowing for both countries. In the Republic of North Macedonia, space was narrowed by 50 basis points throughout the year due to the reduction

Figure 6 Interest Rates of conventional Monetary Policy Tools (except Required Reserve) in the Republic of Albania in 2020

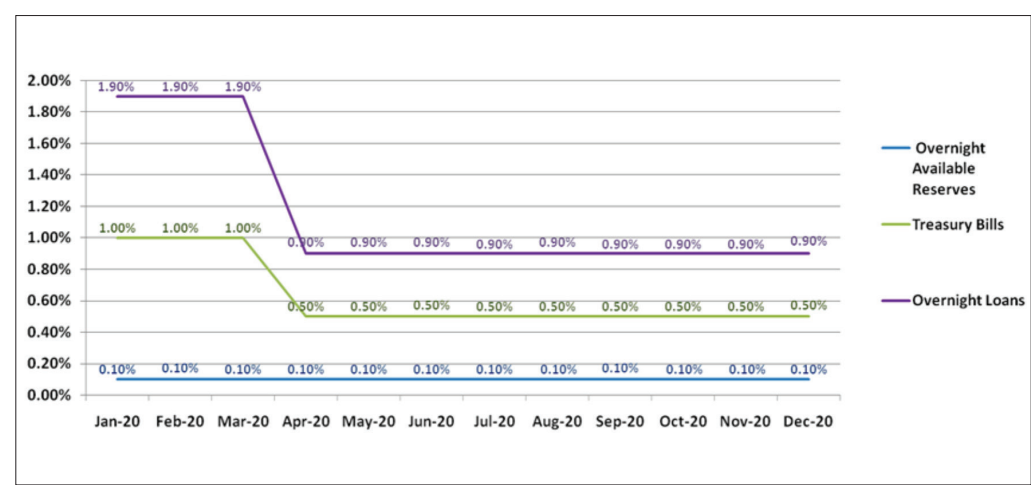

Source: Bank of Albania (2020b). 
of the interest rate on overnight loans from $2.50 \%$ to $2.25 \%$ in March and to $2.00 \%$ in April and thus remained unchanged until the end of 2020. On the other hand, in the Republic of Albania, space was narrowed by 100 basis points due to the reduction of only the interest rate on overnight loans from $1.90 \%$ to $0.90 \%$ on March 25 and thus remained until the end of 2020. Several unconventional measures during 2020 are being undertaken to help the economy smooth the negative effects of the COVID-19 pandemic situation.

\section{Conclusion}

The pandemic's experience has demonstrated the usefulness of the ECB's monetary policy tools in stabilizing financial markets and mitigating the pandemic's detrimental impact on inflation expectations. The toolkit's measures' flexibility and mutually reinforcing effects have been critical in offering enough accommodation to mitigate the crisis' impact. The COVID-19 pandemic, which offered unprecedented problems to governments but also prompted a robust legislative response, had a significant impact on public budgets in 2020 On both sides of government budgets, the fiscal position was considerably impacted by the necessity to raise expenditure to combat the crisis, as well as decreased fiscal revenues reflecting both the harsh recession and expenditure measures targeting enterprises and consumers. The budgetary changes should help countries get back on track for longterm growth. Unusual crises require unconventional and unusual responses. In general, 2020 was a year in the wake of the pandemic environment. The National Banks of North Macedonia and Albania contributed to the achievement of their goals and the stabilization of market expectations through timely and appropriate measures and enhanced communication with the public. The rapid and timely monetary policy responses, and coordination with fiscal policy, have reduced the impact on the real sector. The main conclusion is that both countries' central banks pursued expansive monetary policies to cope with the COVID-19 pandemic. This expansionary policy was realized through easing in conventional monetary policy tools and not only, and unconventional tools were also applied that have contributed to monetary expansion. In the Republic of North Macedonia, the following changes were evident: The interbank interest rate was reduced from $2.00 \%$ to $1.50 \%$; the overnight loan interest rate was reduced from $2.50 \%$ to $2.00 \%$. In the Republic of Albania, the interbank interest rate was cut by half (from $1.00 \%$ to $0.50 \%$ ), and the overnight loan interest rate was cut by $53 \%$ (from $1.90 \%$ to $0.90 \%$ ). The unconventional tools were used as follows: reactivation of the nonstandard reserve demand measure, expansion of the portfolio of eligible securities, tariff reduction, and extension of the deadlines for loans and the bank's liquidity assessment report by the Central Bank of the Republic of North Macedonia; and debt payment deadlines, suspension of dividend distribution, and lower banking sector electronic systems infrastructure costs by the Central Bank of the Republic of Albania. The limitation of this study is that there isn't an analysis of the economic effects of the measures taken by the monetary policy authorities, given the change of conventional and unconventional tools. This is mainly because it is still too early to conduct such an analysis.
Hadzimustafa, S., Abazi-Alili, H.

The Monetary policy in the Republic of North Macedonia and Republic of Albania during 2020 
Hadzimustafa, S., Abazi-Alili, H.

The Monetary policy in the Republic of North Macedonia and Republic of Albania during 2020

\section{References}

Bank of Albania (2020a). Available at: https://www.bankofalbania.org/Shtypi/Fjalime_intervista_ artikuj/Fjalime/Fjala_e Guvernatorit_Sejko_ne_konferencen_per_shtyp_per_vendimmarrjen_e_politikes monetare_7_tetor_2020.html (1.4.2021).

Bank of Albania (2020b). Available at: https://www.bankofalbania.org/Statistics/Monetary_Financial_ and_Banking_statistics/Interest_rates.html (1.4.2021).

Bank of Albania (2020c). Available at: https://www.bankofalbania.org/Politika_Monetare/Instrumentet/ Rezerva_e_Detyruar/(1.3.2021).

Bank of Albania (2020d). Available at: https://www.bankofalbania.org/Press/On the order of the Bank_of_Albania and the Prime_Minister_on the extension of the deadline of payment_of _loans to enterprises and households.html (1.3.2021).

Bank of Albania (2021). Available at: https://www.bankofalbania.org/About_the_Bank/Brief_history_of_ Bank_of_Albania/(1.3.2021).

Clarida, R. H., Duygan-Bump, B., \& Scotti, C. (2021). The COVID-19 Crisis and the Federal Reserve's Policy Response. Finance and Economics Discussion Series 2021-035. Washington: Board of Governors of the Federal Reserve System. https://doi.org/10.17016/FEDS.2021.035

ECB (2021a). Available at: https://www.ecb.europa.eu/pub/pdf/annrep/ecb.ar_annex2020_statistical_ section ae79ac8ab8.en.pdf (1.12.2021).

ECB (2021b). Available at: https://www.ecb.europa.eu/pub/annual/html/ar2020 4960fb81ae. en.html\#toc12 (1.12.2021).

ECB (2021c). Available at: https://www-ecb-europa-eu.translate.goog/press/key/date/2021/html/ecb. sp211001 ca589c6afc.en.html? _x_tr_sl=en\&__x_tr_tl=sq\&_x_tr_hl=en-GB\&_x_tr_pto=op (1.12.2021).

Hubbard, R. G., \& O'Brien,A.P. (2012). Money, Banking, and the Financial System. New York: Prentice Hall.

Loayza , N. V., \& Pennings, S. (2021). Macroeconomic Policy in the Time of COVID-19: A Primer for Developing Countries. Research and Policy Briefs, no. 28. World Bank, Washington, DC.

Mishkin, F. C. (2019). The Economics of Money, Banking, and Financial Markets. 12th ed. Harlow, UK: Pearson.

MIT (2021). Available at: https://mitsloan.mit.edu/ideas-made-to-matter/economist-stanley-fischercritiques-covid-19-monetary-policies\#: :text=Quoting\%20from\%20his\%20new\%20paper,quickly\%20 than\%20had\%20originally\%20been (20.12.2021).

NBRM (2020a).Available at: https://www.nbrm.mk/statistika-en.nspx (1.4.2021).

NBRM (2020b).Available at: https://www.nbrm.mk/zadolzhitielna_rezerva.nspx (1.4.2021).

NBRM (2020c). Available at: https://www.nbrm.mk/ns-newsarticle-soopstenie-1832020-al.nspx (1.4.2021).

NBRM (2020d). Available at: https://www.nbrm.mk/ns-newsarticle-soopstenie-2942020-al.nspx (1.4.2021).

World Bank (2021). Available at: https://www.worldbank.org/en/region/eca/publication/westernbalkans-regular-economic-report (1.6.2021).

World Development Indicators (2021). Available at: https://databank.worldbank.org/reports. aspx?source=2\&series=NY.GDP.MKTP.KD.ZG\&country=ALB\# (16.12.2021). 